\title{
Evaluation of the Purification Performance of the Kossodo Wastewater Treatment Plant in Ouagadougou
}

\author{
Bienvenue Joceline Sawadogo, ${ }^{1 *}$, Martine Kone1, Rose Yamma ${ }^{1,2}$, Stéphane Nonet ${ }^{3}$, \\ Philippe Walhain ${ }^{3}$, Roseline Kabore ${ }^{4}$, Toltama Sanou4, Théodore Nana1, Amado Ouedraogo', \\ H. Arsène Yonli²
}

${ }^{1}$ National Centre for Scientific and Technological Research (NCSTR), Ouagadougou, Burkina Faso

${ }^{2}$ UFR/SEA, Joseph KI-ZERBO University, Ouagadougou, Burkina Faso

${ }^{3}$ Research and Expertise Center for Water (CEBEDEAU) Liege, Belgium University of Liege-Start Tilman,

Liege, Belgium

${ }^{4}$ National Office of Water and Sanitation (NOWS), Ouagadougou, Burkina Faso

Email: `bienvenuesaw@yahoo.fr

How to cite this paper: Sawadogo, B.J., Kone, M., Yamma, R., Nonet, S., Walhain, P., Kabore, R., Sanou, T., Nana, T., Ouedraogo, A. and Yonli, H.A. (2021) Evaluation of the Purification Performance of the Kossodo Wastewater Treatment Plant in Ouagadougou. Journal of Environmental Protection, 12, 1128-1143.

https://doi.org/10.4236/jep.2021.1212066

Received: September 24, 2021

Accepted: December 13, 2021

Published: December 16, 2021

Copyright $\odot 2021$ by author(s) and Scientific Research Publishing Inc. This work is licensed under the Creative Commons Attribution International License (CC BY 4.0).

http://creativecommons.org/licenses/by/4.0/ (c) (i) Open Access

\begin{abstract}
The efficiency of a wastewater treatment system is classically measured by the quality of its discharge into the aquatic environment. This quality can only be achieved if certain aspects are taken into account, such as the design and operation of the system in place. The objective of the present work is to evaluate the purification performance of this system after 17 years of operation. It should be noted that the lagoon plant (WWTP) has a total of eight basins, three of which are anaerobic (ANA). The evaluation of the physicochemical and microbiological parameters in the anaerobic basins and in the maturation basins allowed us to note slightly basic $\mathrm{pH}$ values in the maturation basins (8.7 to 9.2) against values from 6.8 to 7.4 in the anaerobic basins. Also, the values in terms of organic and bacteriological pollution have also evolved. For $\mathrm{COD}$ and $\mathrm{BOD}_{5}$, we obtained respectively abatements of more than $73 \%$ for filtered COD, $55 \%$ for gross $\mathrm{COD}$ and $81 \%$ for $\mathrm{BOD}_{5}$ even if the residual concentrations do not respect the standards of wastewater discharge in our country. Also, the residual concentrations of ammonia nitrogen in the output effluents (on average $12.43 \mathrm{mg} / \mathrm{L}$ ), do not meet the standard of discharge into surface waters of Burkina Faso $(1.29 \mathrm{mg} / \mathrm{L})$. Thus, nutrients such as nitrogen and phosphorus pollution have average abatement rates of $31 \%$ and $27 \%$ respectively. In sum, we can say that the lagoon system set up does not meet the requirements in terms of quality of discharges, which remains an environmental problem for the receiving environment.
\end{abstract}




\section{Keywords}

Mixed Wastewater, Natural Lagooning, Nitrogen, Phosphorus

\section{Introduction}

Urban wastewater management is a major environmental problem in the world and particularly in Africa where huge quantities of wastewater are discharged into the environment without treatment. This issue is all the more crucial in sub-Saharan Africa, given the insufficiency of adequate wastewater collection and treatment systems. Burkina Faso is no exception to this situation, even though initiatives have been taken to improve access to sanitation for the population. In 1995, Burkina Faso developed a Strategic Sanitation Plan for the city of Ouagadougou (SSPO), which aims to implement effective strategies to improve the management of wastewater and excreta, and actions to increase the population's access to improved sanitation. One of the major activities of this project is the construction in 2004 of a lagoon-based wastewater treatment plant in Kossodo, Ouagadougou. Lagooning, an extensive water purification process, appears to be the most suitable solution for the Sahel countries, including Burkina Faso, because of its simplicity, its flexibility of operation, and above all its low installation and maintenance costs, even if though it requires a large area of land for its implementation. Therefore, the Kossodo Wastewater Treatment Plant (WWTP) was set up in 2004 to treat the wastewater of the city of Ouagadougou. To better understand the design and operation of this plant, several studies have been conducted and the Kossodo plant is continuously monitored to ensure the quality of the treated effluent in accordance with the standards for wastewater discharge into surface waters in Burkina Faso, or for its reuse in agriculture. This plant, which collects wastewater from the food processing industry (brewery and slaughterhouse) and from some administrative buildings in the city of Ouagadougou, seems to be both a technical and economic solution, given the possibility of reusing the effluent for market gardening downstream from the site. What about its operation in its current state? Its general objective is to evaluate the efficiency of the operation of the Kossodo WWTP after 17 years of operation and to possibly provide solutions to improve the quality of effluents before their discharge or reuse. More specifically, it is:

1) To evaluate the global physicochemical and organic pollution parameters: Temperature, $\mathrm{pH}$, Dissolved Oxygen, $\mathrm{COD}, \mathrm{BOD}_{5}$, and TSS in the raw influent at the entrance of the plant, specifically in the anaerobic basin; and the effluent at the exit of the plant, i.e. the maturation basins;

2) To evaluate the parameters which reveal faecal contamination such are: coliforms faecal matter including $E$. coli from the raw influent and the effluent;

3) To deduce the purification yields for the different lagoons and for the whole treatment process for the elimination of organic matter and bacterial pollution during the study period and to compare them to the data of the literature. 


\section{Materials and Method}

\subsection{Materials}

The principle of lagooning is based on the self-purification phenomena occurring in ponds, due to biological (predation, antagonism, competition, parasitism...), physical (solar radiation, temperature, sedimentation...) and chemical $(\mathrm{pH}$, germicidal products, heavy metals...) factors in developing countries with a relatively warm climate, lagooning is seen as a first choice system for wastewater treatment due to its low maintenance and operating costs.

A typical lagoon-based wastewater treatment system consists of anaerobic, facultative and maturation ponds.

\subsubsection{Geographic Localisation and Climatic Conditions}

The study was carried out on the wastewater treatment plant of the city of Ouagadougou, located in Kossodo near the industrial zone. Kossodo is in the north of the city of Ouagadougou, in the municipality of Nongremassom. The operation of the Kossodo WWTP is governed by the Sudan-Sahel climate of Ouagadougou, which is marked by a long dry period with significant sunshine.

\subsubsection{Origin and Composition of Wastewater Submitted to Treatment}

The Kossodo WWTP receives wastewater from the city of Ouagadougou, the Sopatel Hotel (formerly Silmandé), the Yalgado Ouédraogo Hospital, the refrigerated slaughterhouse and the Burkina Faso brewery (BRAKINA), (Figure 1). The wastewater from the slaughterhouse and the brewery undergoes pre-treatment before being discharged into the sewer system. At the brewery, the pre-treatment is simply done by decantation in the decanter to eliminate settleable solids. to eliminate settleable solids. At the slaughterhouse, the pre-treatment is first done by a physical treatment (screen followed by a static decanter) associated with a settling in three anaerobic tanks.

\subsubsection{The Different Types of Basins Encountered in the Lagoon System}

\section{- Anaerobic basins}

Figue 2 shows clearly the station structuration. These are the first types of ponds found in this lagoon system. They are generally between 2 and $5 \mathrm{~m}$ deep (Table 1) and must receive large quantities of water with an organic load of between $100 \mathrm{~g} \mathrm{BOD}_{5} / \mathrm{m}^{3} /$ day and $400 \mathrm{~g} \mathrm{BOD}_{5} / \mathrm{m}^{3} /$ day [1]. They operate as open septic tanks and their main function is $\mathrm{BOD}_{5}$ removal. Indeed, a welldesigned anaerobic tank that is not under-loaded can achieve a $\mathrm{BOD}_{5}$ removal of $60 \%$ at $20^{\circ} \mathrm{C}[1] . \mathrm{BOD}_{5}$ removal is achieved by the sedimentation of settleable materials and their anaerobic digestion by the resulting sludge layer. This process is particularly intense at temperatures above $15^{\circ} \mathrm{C}$ with the production of biogas (about 70\% methane and 30\% carbon dioxide). However, anaerobic ponds have the disadvantage of often causing foul odours due to the emission of hydrogen sulfide. In order to avoid these problems, some authors recommend that the organic load by volume be less than $400 \mathrm{~g} \mathrm{BOD}_{5} / \mathrm{m}^{3}$. 


\section{- Facultative basins}

Facultative ponds are generally used for organic load removal and for nitrogen and phosphorus removal. Their role in the elimination of bacterial pollution is no less important. They are designed for $\mathrm{BOD}_{5}$ removal based on a relatively low surface load of $100 \mathrm{~kg}$ to $400 \mathrm{~kg}$ of $\mathrm{BOD}_{5} / \mathrm{ha} /$ day to allow good algal development. They are generally between 1 and $2 \mathrm{~m}$ deep (Table 1), with a high residence time ( 5 to 30 days). The water from the facultative pond is dark green in colour due to the large number of microalgae. They can sometimes appear red or pink in case of overload due to the presence of purple sulphur-reducing bacteria

\section{- Maturation basins}

They play the role of disinfectant. Indeed, their role is to ensure especially a good elimination of pathogens such as bacteria of faecal origin and viruses present in the effluent from the facultative basin. Maturation ponds are usually $\leq$ $1 \mathrm{~m}$ deep (Table 1 ). This allows good light penetration and consequently the maintenance of aerobiosis through a very intense photosynthetic activity throughout the basin. Maturation basins contain a greater diversity of algae than

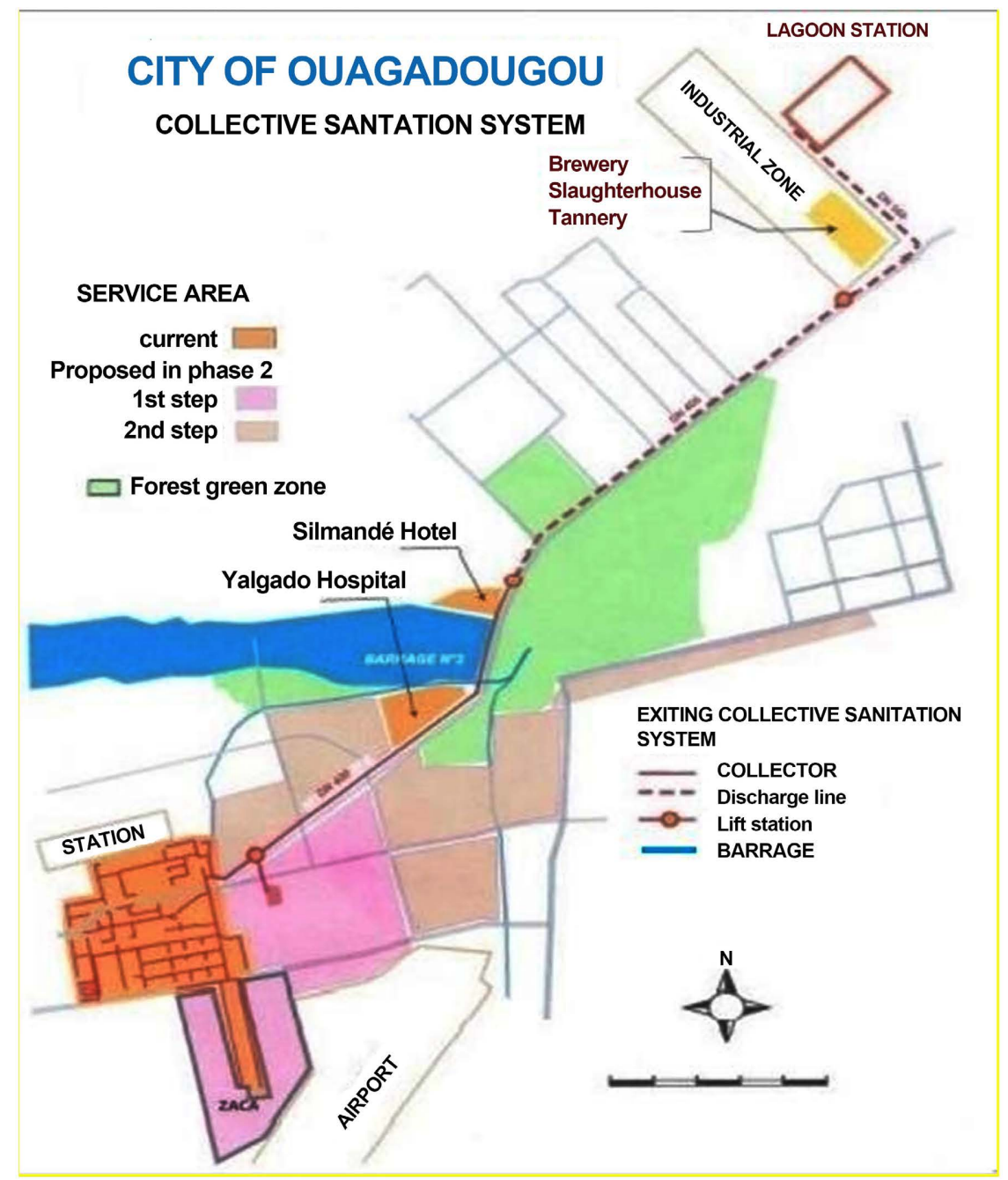

Figure 1. Plan of the collective sewerage network of Ouagadougou (source ONEA). 


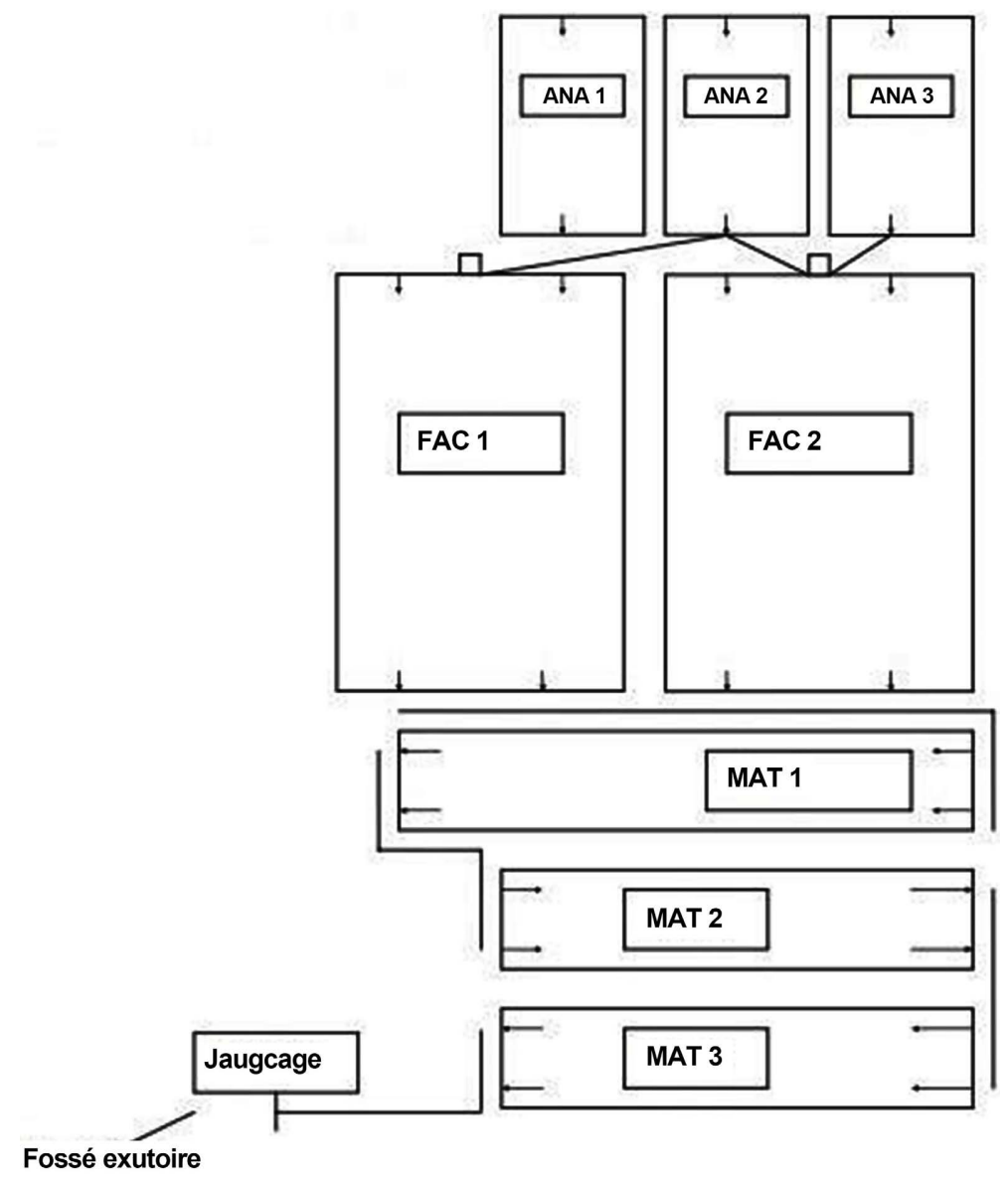

Figure 2. Schematic plan of the Kossodo lagoon station (source ONEA).

Table 1. Characteristics of differents basins.

\begin{tabular}{cccccc}
\hline Designation & AB & FB & M1B & B2M & B3M \\
\hline Depth $(\mathrm{m})$ & 4 & 1.8 & 1.20 & 1.20 & 1.20 \\
Surface $\left(\mathrm{m}^{2}\right)$ & 0.37 & 3 & 1.47 & 0.37 & 0.37 \\
Volume $\left(\mathrm{m}^{3}\right)$ & 18,500 & 54,000 & 29,400 & 7400 & 7400 \\
Duration time $(\mathrm{j})$ & 3 & 16 & 6 & 3 & 3 \\
\hline
\end{tabular}

Source: [3].

facultative ponds but less algal biomass in concentration. In case of low organic load of the wastewater at the WWTP inlet, the facultative and maturation ponds can be covered with duckweed, which prevents a good light penetration and at the same time a decrease of the photosynthetic activity necessary for their good functioning. This dysfunction can be solved by sedentary ducks in the basins or by the use of chemical inhibitor [2].

The residence times are respectively 3 days for the anaerobic ponds, 16 for the facultative ponds, 5 days for the maturation pond 1 and 3 days for the maturation ponds 2 and maturation 3 . 


\subsubsection{Physicochemical Parameters Analysed}

\section{- The hydrogen potential $(\mathrm{pH})$}

It reflects the acidity or alkalinity of the environment. It is one of the most important parameters in the process of eliminating pathogens and nutrients, as well as controlling odours. A pH that is too acidic inhibits the activity of methanogenic bacteria and causes unpleasant odours. However, a $\mathrm{pH}$ that is too basic reduces microbial activity. $\mathrm{pH}$ values above 8.5 would promote the inactivation of E. coli.

\section{- Temperature}

Temperature is a very important factor in the operation of wastewater treatment plants. It influences the kinetics of reactions. Indeed, the biological activity of a plant varies according to the temperature. It becomes important with high temperature. The temperature is one of the most important factors in the functioning of lagoons. Indeed, the dimensioning of the admissible loads in the anaerobic basins and the elimination of the $\mathrm{DBO}_{5}$ are function of the temperature, as well as that of the optional basin by taking into account the temperature of the coldest month.

\section{o Conductivity}

Conductivity measures the ease with which water can conduct an electric current due to the presence of dissolved salts. Most of the dissolved matter in water is in the form of electrically charged ions. The quantity of dissolved salts in water is therefore obtained by measuring the conductivity. It also varies according to the water temperature and it is more significant when the temperature increases.

\section{- Faecal contamination indicators}

The indicators of faecal contamination as their name indicates are microorganisms that have a faecal origin. Their presence in food or water is the consequence of contact with faecal matter. Faecal contamination indicators are always present in wastewater at varying levels. However, there is no universal indicator but each indicator has its own characteristics. Faecal coliforms are a subgroup of total coliforms; they belong to the Enterobacteriaceae family. They are aerobic and facultative anaerobic bacteria, Gram-negative, rod-shaped, oxidase-negative, which can ferment lactose into acid and gas at a temperature of $44.5^{\circ} \mathrm{C} \pm 0.2^{\circ} \mathrm{C}$ in $24 \pm 2 \mathrm{~h}$. The most commonly represented species in this group is Escherichia coli; other species such as Enterobacter, Klebsiella and Citrobacter may be associated with this group to a lesser extent. The use of faecal coliforms as an indicator of faecal contamination is more appropriate in wastewater treatment; currently, Escherichia coli is the most widely used and reliable indicator bacterial of faecal contamination because it can indicate contamination from the faeces of warm-blooded animals.

\subsubsection{Mechanisms of Pollution Removal}

Several factors interact together to allow the degradation of carbonaceous load in a facultative lagoon system:

\section{o Algae}


Algae are also called photosynthetic microorganisms because they contain chlorophyll, which is why lagoons are green. This chlorophyll allows them to use sunlight as a source of energy, which is the basis of the photosynthesis process. The algae thus assimilate mineral salts and gas carbon dioxide from wastewater to grow and release oxygen through photosynthesis [4].

\section{- Bacteria}

These are microorganisms that can break down degrade a large part of the organic matter. They release the products of their degradation in the form of carbon dioxide and soluble matter into the environment [4]. Two types of bacteria are involved in the lagoon treatment process; anaerobic bacteria that can grow without oxygen and aerobic bacteria that require oxygen for their synthesis. In lagoons, anaerobic bacteria act at the bottom of the lagoons and in the sludge. Aerobic bacteria are active on the surface. The oxygen necessary for their respiration comes on the one hand from the exchanges between the air and the water (agitation of the water surface by the air) and on the other hand by the activity of the microscopic algae suspended in the water.

The removal of $\mathrm{BOD}_{5}, \mathrm{COD}$ and TSS is based on this symbiotic relationship between algae and bacteria. This phenomenon is mainly observed in facultative and maturation ponds due to their shallow depth.

\section{o Settling}

It plays an important role in the process of eliminating the organic load. In anaerobic ponds with almost no light penetration, particulate organic matter in the wastewater settles and forms sediment at the bottom of the pond. The anaerobic bacteria degrade the sediments resulting from the settling of the organic matter. This process allows the elimination of the major part of the SS. Suspended solids constitute a good part of the organic pollution; their reduction therefore contributes to a better performance of BOD and COD [4].

\subsubsection{Factors Influencing Nutrient Removal}

\section{- Nitrogen}

Nitrogen is found in water in organic form of ammonium $\left(\mathrm{NH}_{4}^{+}\right)$and nitrate $\left(\mathrm{NO}_{3}^{-}\right.$, in low proportion) in wastewater. Its elimination in these waters can be done in several ways: uptake assimilation by algae, volatilization (transformation of ammonium into ammonia $\left(\mathrm{NH}_{3}\right.$ gas), nitrification (oxidation of ammonium into nitrate), denitrification (reduction of nitrates into nitrogen gas, $\mathrm{N}_{2}$ ), retention in sludge accumulated at the bottom of the ponds and the adsorption of ammonium by phytoplankton, this pathway being rarely mentioned. Each of these reactions is independent of the environment and oxidation state. According to [4], there is no removal of total nitrogen in the anaerobic pond, but only transformed nitrogen with some of the organic nitrogen (mainly urea and amino acids) being converted to ammonium by the ammonification process. Most of the nitrogen is removed in the facultative and maturation pond through incorporation of ammonia into the algal cells, although at high $\mathrm{pH}$ it can be removed by volatilization into the atmosphere [4]. 


\section{- Phosphorus}

Its removal in lagoons is controlled by a set of physicochemical reactions. Indeed, the mobility of phosphorus is controlled by the $\mathrm{pH}$ and the redox potential. In acidic environments, inorganic phosphorus reacts with ferric ions and aluminium to form insoluble compounds that precipitate [5]. But at basic $\mathrm{pH}$, it precipitates preferably with calcium.

\subsubsection{Factors Influencing Microbial Decontamination}

\section{1) Physical factors}

\section{o Solar radiation}

Solar radiation has been known for a long time as one of the factors determining the mortality of pathogens in a natural lagoon system. Some authors have demonstrated the action not only of ultraviolet light but also of wavelengths corresponding to visible light on the elimination of many bacteria indicative of faecal contamination, [6]. In addition to this lethal role for microorganisms, sunlight also plays an important role in the oxygen production process through photosynthesis. However, the inactivation of bacteria is proportional to the intensity of sunlight and depends on the type of radiation.

\section{- The temperature}

The temperature is an essential factor in the reduction of pathogens. It affects the kinetics of reactions in lagoons. At high values, it is detrimental to the bacteria. However, it should be noted that several studies show that temperature alone is not the main cause of disinfection in the sedimentation, but also a catalyst under the control of other parameters.

\section{o Sedimentation}

Sedimentation plays a singular role in the elimination of pathogenic germs. Indeed, in the ponds, it causes an apparent disappearance of bacteria that change physical compartment, [4] and move from the surface of water where the samples are taken for bacteriological measurements to be go to at the bottom of the pond. This settling process is directly related to the TSS to which they are attached. The bacteria are thus dragged to the bottom by the TSS, sediment and die. Sedimentation is also considered to be one of the dominant mechanisms for the removal of helminth eggs in lagoons, however, parasite eggs and cysts can survive for a long time in the settled sludge at the bottom of the lagoon.

\section{- Residence time}

Hydraulic residence time is the time that wastewater remains in a treatment system before being discharged. It plays a predominant role in the settling of sediments and therefore in the elimination of pathogens.

\section{2) Chemical Factors}

\section{- The $\mathrm{pH}$}

The $\mathrm{pH}$ is a parameter to be taken into account in the disinfection of pathogens. Indeed, microorganisms are very sensitive to $\mathrm{pH}$ variations. A $\mathrm{pH}$ that is too acidic or too basic leads to the death of bacteria. Microorganisms in natural lagoons develop better in environments with a $\mathrm{pH}$ close to neutrality. In addition, $\mathrm{pH}$ interacts with light radiation to cause inactivation of pathogens [4]. 


\section{- Algal toxins}

Algal activity in lagoons affects bacterial survival in two ways. First, algal photosynthesis increases $\mathrm{pH}$ and dissolved oxygen. These parameters become harmful to the bacteria in the presence of light. On the other hand, the algae and suspended matter present in the surface layer of the ponds reduce the lethal effect of light on the bacteria by absorbing part of the light radiation.

\section{3) Biological factors}

A wide variety of micro fauna inhabit lagoons. These feed on microorganisms present in the water. The algae and bacteria are in turn consumed by the zooplankton. This predation contributes very strongly to the biological processes of disinfection of the bacteria in the lagoons.

\section{4) Sampling and analysis methods}

A preliminary visit to the Kossodo WWTP was carried out during this phase in order to get a better understanding of the site for a best organisation of the field work. We therefore chose to proceed to a sampling by basin on two different basins, namely, the anaerobic basin which receives the waste water at the entry of the station and at the exit of the basin of maturation 3 which represents the purified water ready to be rejected in nature. Then we proceeded to in situ analyses on parameters such as temperature, $\mathrm{pH}$, conductivity. Finally, we carried out laboratory analyses for the other parameters, before completing with the analysis and interpretation of the results.

\subsection{Methods of Analysis}

\subsubsection{Physicochemical Parameters}

The global physicochemical parameters such as temperature $\left(\mathrm{T}^{\circ}\right)$, hydrogen potential $(\mathrm{pH})$, conductivity, dissolved oxygen were measured in situ by means of a multi-metre on the sample taken in each basin. The different parameters analyzed are listed in Table 2.

\section{- Chemical Oxygen Demand (COD)}

It characterizes the quantity of dissolved oxygen necessary to chemically oxidize the totality of the oxidisable matter contained in an effluent. It allows to evaluate the totality of the oxidizable substances which includes those which are biodegradable. COD is measured by hot oxidation in a strongly acidified environment for 2 hours. The oxidant commonly used is potassium dichromate.

\section{- Suspended solids (SS)}

Suspended solids are composed of organic and mineral matter suspended in water (sand, clay, organic products, etc.). They give a cloudy appearance to pond water and hinder the penetration of light necessary to sustain life. They constitute solid pollution when they are present in large quantities in the water. These solids present in wastewater can be separated by filtration or centrifugation. The measurement method adopted for TSS is the differential weighing by filtration on GFC filter and drying at $105^{\circ} \mathrm{C}$ (standard method).

\section{o Nitrogen}

The forms of nitrogen evaluated in the present study are nitrite, nitrate and 
ammonia nitrogen.

These different forms of nitrogen are determined by the Palintest method.

\section{o Phosphorus}

Phosphorus is found in two forms in domestic wastewater: mineral phosphorus represented by orthophosphates in large quantities and organic phosphorus in smaller quantities. It is a limiting factor for the development of algae in ponds. The measurement of these parameters makes it possible to appreciate the conditions of biological treatment of the effluents and the risks related to the eutrophication of the receiving waters. The measurements of total phosphorus as well as orthophosphates were made following the Palintest method and the reading of the results by spectrophotometry at specific wavelengths for each parameter.

\subsubsection{Faecal Pollution Indicators}

The method by surface spreading using balls and rakes on nutrient agar was used for the enumeration of indicators of faecal contamination (Faecal Coliforms including Escherichia coli). The principle of this method is the following: after homogenization of the sample to be analysed, a dilution in cascade to the tenth was carried out with a physiological solution (RINGER). A volume of 0.1 $\mathrm{ml}$ of the sample at each dilution was inoculated on petri dishes of $90 \mathrm{~mm} \mathrm{di}$ ameter containing a specific culture medium for each microorganism. These culture media were previously poured into the petri dishes.

\section{- Faecal coliforms}

Faecal coliforms were plated on a specific culture medium Chromocult coliform Agar ES and incubated at $44.5^{\circ} \mathrm{C}$ for 18 to $24 \mathrm{~h}$. Escherichia coli seeded on Chromocult coliform Agar ES culture medium was incubated at $44.5^{\circ} \mathrm{C}$ for 18 to 24 h. E. coli gave blue or purplish blue colonies and faecal coliforms gave pink colonies.

Table 2. Different parameters table.

\begin{tabular}{|c|c|c|}
\hline Parameters & Unit & Method \\
\hline $\mathrm{pH}$ & - & pH-NF T 90-008 \\
\hline Temperature & ${ }^{\circ} \mathrm{C}$ & NF 27888 \\
\hline Conductivity & $\mu \mathrm{S} / \mathrm{cm}$ & NF 27888 \\
\hline $\mathrm{DCO}$ & $\mathrm{mg}$ of $\mathrm{O}_{2} / \mathrm{L}$ & $\begin{array}{l}\text { Standard Methods for examination of } \\
\text { water and waste water method 5220D }\end{array}$ \\
\hline $\mathrm{DBO}_{5}$ & $\mathrm{mg}$ of $\mathrm{O}_{2} / \mathrm{L}$ & OxiTop method \\
\hline MES & $\mathrm{mg} / \mathrm{L}$ & NF T 90-105 \\
\hline $\mathrm{NH}_{4}^{+}$ & $\mathrm{mg} / \mathrm{L}$ & NF T 90-023. \\
\hline $\mathrm{NO}_{3}^{-}$ & $\mathrm{mg} / \mathrm{L}$ & NF T 90-023. \\
\hline P tot & $\mathrm{mg} / \mathrm{L}$ & NF T 90-023. \\
\hline $\mathrm{P}-\mathrm{PO}_{4}^{3-}$ & $\mathrm{mg} / \mathrm{L}$ & NF T 90-023. \\
\hline $\mathrm{CF}$ & $\mathrm{UFC} / 100 \mathrm{~mL}$ & Spreading \\
\hline E. coli & $\mathrm{UFC} / 100 \mathrm{~mL}$ & Spreading \\
\hline
\end{tabular}




\section{Resultats and Discussion}

\section{- Variation in $\mathrm{pH}$}

Figure 3 shows the variation in $\mathrm{pH}$ of the raw influent and effluent at the outlet of the maturation tank. The $\mathrm{pH}$ values between 6.8 and 10.4 show a high variability of the influent at the head of the plant. This variation in raw wastewater $\mathrm{pH}$ would be largely related to the characteristics of the raw wastewater from the brewery. The low $\mathrm{pH}$ values (minimum $\mathrm{pH}$ 6.8) are explained by the influence of acidic water discharges due to the use of phosphoric acid by the brewery for tank disinfection. On the other hand, the basic $\mathrm{pH}$ values (maximum $\mathrm{pH} 10.4$ ) are due to the use of caustic soda in the washing of tanks and bottles in the brewery. In addition, the $\mathrm{pH}$ in the facultative and maturation ponds was raised to 8 . It reaches maximum values of 8.72 in the effluent from the maturation tanks. $\mathrm{pH}$ values that are too basic can influence the operation of the anaerobic tanks, which is governed by the methanogenic bacteria whose optimum operating range is between 6.5 and 7.2. Anaerobic digestion normally takes place at $\mathrm{pH}$ levels between 6 and 8. Below 6, the activity of the methanogenic bacteria decreases rapidly and can be completely stopped at $\mathrm{pH}$ levels of 5.5 and above, while the acid generating bacteria continue to produce volatile fatty acids (VFAs) at pH levels around 4.5 [4]. In contrast to the anaerobic ponds, the maturation ponds show high $\mathrm{pH}$ values with an average of 8.72 , demonstrating good mineralization during the process. These results corroborate those of [6] at the outlet of the maturation basin of Taourirt in arid climate with an average of 8.19.

The $\mathrm{pH}$ of the treated wastewater of the WWTP, ranging on average between 6.45 and 8.80 , respect the standards of discharge of treated wastewater into surface waters in Burkina Faso which is between 6.5 and 9.

\section{- Variation in electrical conductivity}

The conductivities of the wastewater entering the WWTP are highly variable and high with average values of $1628.13 \mu \mathrm{S} / \mathrm{cm}$ and maximum and minimum values of $4390 \mu \mathrm{S} / \mathrm{cm}$ and $605 \mu \mathrm{S} / \mathrm{cm}$ respectively. However, they are higher on average in the other ponds but less variable, with an average of 1937.92 at the outlet of the maturation pond. Conductivity values that are too high can reduce or even inhibit crop growth. For this the conductivity of an irrigation water should not exceed $3000 \mu \mathrm{S} / \mathrm{cm}$, [7], cited by [4].

\section{- Temperature variation}

Water temperatures at the inlet to the treatment plant are highly variable with a minimum of $22^{\circ} \mathrm{C}$ and a maximum of $36.8^{\circ} \mathrm{C}$. The average raw influent temperature is $31.45^{\circ} \mathrm{C}$, relatively higher than the outlet effluent temperature of $27.22^{\circ} \mathrm{C}$. In general, the temperature variation ranges reflect the influence of local climatic conditions. The temperature value plays a very important role in the efficiency of biological purification because it can inhibit bacteriological activity. Nevertheless, the temperatures recorded during this study respect the standards for discharge into surface waters of Burkina Faso, which are $40^{\circ} \mathrm{C}$.

- Variation in $\mathrm{COD}, \mathrm{BOD}_{5}$ and TSS 


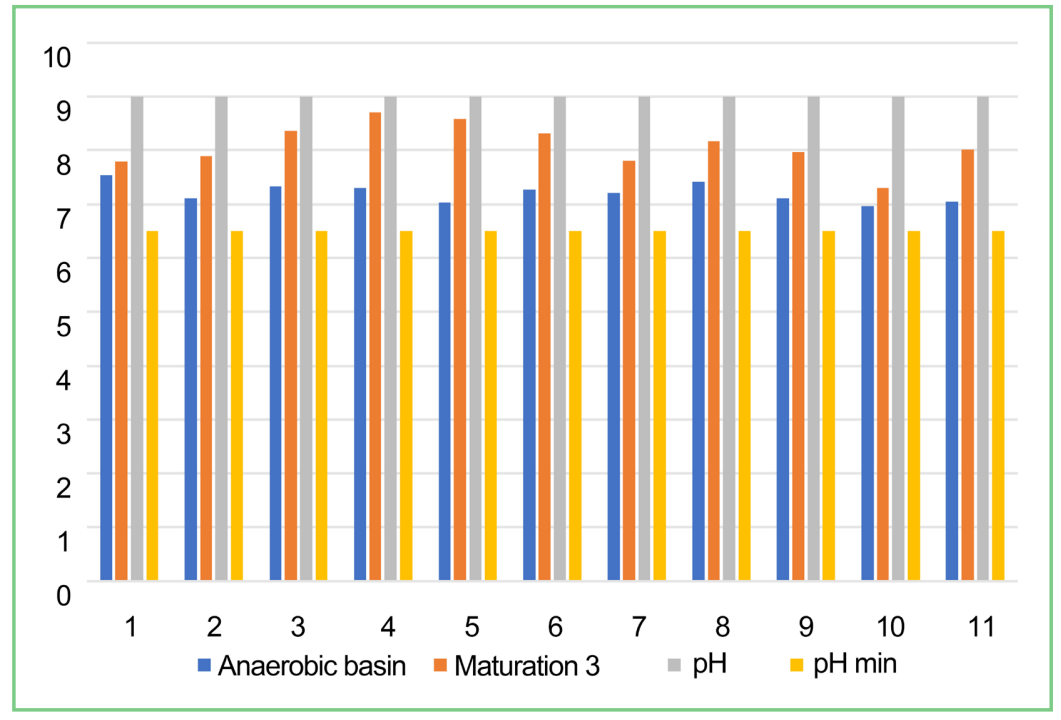

Figure 3. Variation in $\mathrm{pH}$ during six months of monitoring.

Figure 4 shows the different $\mathrm{COD}$ and $\mathrm{BOD}_{5}$ removal rates in the maturation basins at the plant outlet and in the anaerobic basin at the head of the plant.

The COD of the raw influent of Kossodo is composed on average of $34 \%$ of particulate COD [4]. This value is comparable to that reported by [2] with $45 \%$ on raw wastewater from the same plant, thus showing a predominance of dissolved forms of COD due certainly to the pretreatments carried out on the wastewater discharges from the brewery and the slaughterhouse. Considering the flow reported by [2], the volumetric organic loads contributed by the raw water of Kossodo are in accordance with literature data which report allowable loads of 100 to $400 \mathrm{~g} \mathrm{BOD}_{5} / \mathrm{m}^{3} /$ day [1]. Measurements taken on raw water admitted to the Kossodo WWTP show very high concentrations of both COD and BOD $_{5}$ with an average of $2020 \pm 248 \mathrm{mg} / \mathrm{L}$ for COD and $1238 \pm 199 \mathrm{mg} / \mathrm{L}$ for $\mathrm{BOD}_{5}$. The reduction rates at the plant outlet are between $73 \%$ for filtered COD, $55 \%$ for gross $\mathrm{COD}$ and $81 \%$ for $\mathrm{BOD}_{5}$ (Figure 4). The results obtained in terms of $\mathrm{BOD}_{5}$ reduction are clearly below those of [8], which obtained 99.3 $\mathrm{mg} / \mathrm{L}$ of $\mathrm{BOD}_{5}$ at the inlet against $4.43 \mathrm{mg} / \mathrm{l}$ after treatment, i.e. an efficiency of over $91 \%$.

Analyses conducted on the Kossodo influents give relatively low TSS concentrations ranging from $135 \mathrm{mg} / \mathrm{L}$ to $103 \mathrm{mg} / \mathrm{L}$ with an average of $118 \pm 9 \mathrm{mg} / \mathrm{L}$. The low TSS concentrations can be explained by the pre-treatment performed upstream including the lagoon system consisting of three anaerobic ponds at the slaughterhouse and the primary settling system at the brewery. These pre-treatment systems significantly reduce the TSS concentrations in the raw water. Nevertheless, the TSS concentrations of the water in the maturation ponds meet the discharge standards for treated wastewater in Burkina Faso $(200 \mathrm{mg} / \mathrm{L})$.

o Nutrient Variation ( $\mathbf{N}-\mathbf{N H}_{4}^{+}, \mathbf{N}-\mathrm{NO}_{3}^{-}, \mathbf{P t}, \mathbf{P}-\mathbf{P O}_{4}^{3-}$ )

The evaluation of nutrients content was based on measurements of ammonia nitrogen, nitrates, total phosphorus and orthophosphates. Thus, the measurements 


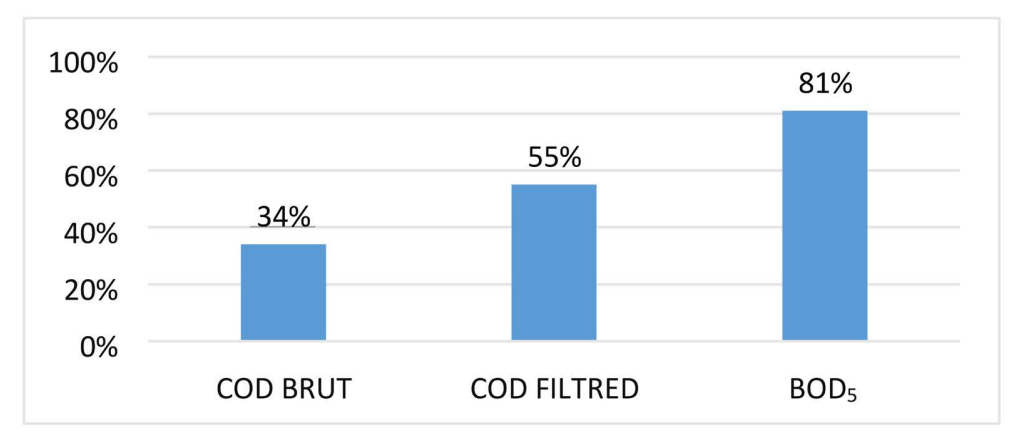

Figure 4. Differents abatements of organic pollution in the maturation basin.

carried out on the raw wastewater of the Kossodo microphyte lagoon plant give ammonia nitrogen concentrations evolving in a range of values between 16 and $5 \mathrm{mg} / \mathrm{L}$ with an average of $12.43 \mathrm{mg} / \mathrm{L}$. This reflects a high variability of the influent at the WWTP inlet. However, ammonia nitrogen concentrations increase in the anaerobic tanks with an average of $21 \pm 16 \mathrm{mg} / \mathrm{L}$ before dropping in the maturation tanks ( $3 \pm 7 \mathrm{mg} / \mathrm{L}$ ), which represents a reduction of about $85 \%$. The reduction of ammonia nitrogen in these ponds may be due to uptake by algae and recycling by zooplankton [6]. Analyses performed on raw wastewater from the Kossodo WWTP show very high average nitrate values $23 \pm 4 \mathrm{mg} / \mathrm{L}$. Overall, nitrate concentrations are decreasing in the two basins of the system [9]. They are on average $16 \pm 7 \mathrm{mg} / \mathrm{L}$ for the anaerobic ponds against $11 \pm 5 \mathrm{mg} / \mathrm{L}$ for the maturation ponds, i.e. a reduction of $31 \%$. Even with this evolution, the actual concentrations remain high to be released into nature. For phosphorus pollution, total phosphorus yields are on average $24 \% \pm 18 \%$ and $27 \% \pm 26 \%$ for orthophosphates. These yields are clearly unsatisfactory and show a poor elimination of nitrogen during treatment. However, natural lagooning is a technology that has proven itself through numerous studies in the treatment of domestic and industrial wastewater [10] [11]. The less brilliant results recorded, in this study is due to a dysfunction in the circuit that we attribute on the one hand to the treatment plant of sludge set up nearby which discharges part of the sludge directly into the maturation tank, and on the other hand to the fact that the tanks are not cleaned periodically, which can lead to the rise of sludge and therefore a failure of the system at a point in time

\section{- Removal of bacterial pollution}

The performances in terms of bacterial pollution removal are particularly low. The different purification efficiencies of $68 \%$ for faecal coliforms and $63 \%$ for total coliforms (Table 3 ) indicate a poor elimination of bacterial pollution, mainly in the anaerobic tank designed for this purpose. This s due to the fact that for almost three years, the drying beds of the faecal sludge plant (FSP) have been directly connected to the treatment plant. Therefore, the leachates from the FSP are directly sent to the maturation basins of the WWTP whereas it would have been more appropriate to send them upstream the process, i.e. to the anaerobic basins. These leachates being very loaded with faecal matter will contaminate the 
disinfection process already started by the WWTP, and considering that the residence time is not long ( 3 to 5 days) in the maturation basins, this does not allow a good disinfection. These yields that we obtained are clearly below those of [4] on the same station with purification yields of over $99.999 \% E$. coli, as well as efficiencies of more than $99.999 \%$ for faecal coliforms were obtained with reduction averages of up to $5.6 \mu \mathrm{log}$ for faecal coliforms in general and specifically $5.37 \mu \log$ for $E$. coli. The reduction performances also remain lower than the performances recorded by [6] on the lagoon system in Morocco with an operation period of 4 years and a residence time of 18 days.

\section{Proposed Solutions}

The evaluation of the purification performance of the Kossodo WWTP after 17 years of operation has revealed some dysfunctions, likely to hinder the proper operation of the WWTP, given the drop in efficiency of some parameters observed during the study. In this section, solutions will be proposed to reduce these malfunctions. Difficulties in evaluating the exact organic loads admitted to the Kossodo WWTP.

During our period of study, we were confronted with the challenge in determining the real in and out loads of the system and the real variations of the flow per day. Therefore, it was difficult to know if the plant is under or overloaded. In addition, we were not able to calculate the actual residence times of the water in the basins. We recommend the installation of a flow meter at the entrance of the station.

\section{- Problem of pump maintenance and high $\mathrm{pH}$ variation}

During our study we recorded periods when the pumps were broken down, or when there was no water inflow due power shortage or a very low inflow, which hinders the proper functioning of the anaerobic ponds that could operate under load and behave as facultative ponds. Moreover, when the pumps are not working, there is not a good homogenization of industrial wastewater with domestic wastewater. Indeed, industrial wastewater has a high $\mathrm{pH}$ which can be detrimental to the functioning of methanogenic bacteria and microorganisms responsible for the degradation of organic matter in the ponds. To solve this problem, we propose regular pump maintenance.

- Sludge accumulation and presence of solid objects in the basins

During our study we observed sludge build-up in the anaerobic tanks. The

Table 3. Differents reductions table.

\begin{tabular}{cccccc}
\hline parameters & $\begin{array}{c}\text { Average } \\
\text { input }\end{array}$ & $\begin{array}{c}\text { Average } \\
\text { output }\end{array}$ & Efficiency \% & $\begin{array}{c}\text { Reduction } \\
\mu \log \end{array}$ & $\begin{array}{c}\text { Samples } \\
\text { numbers }\end{array}$ \\
\hline FC & $4.2 \mathrm{E}+08$ & $2.85 \mathrm{E}+06$ & 68 & 1.35 & 27 \\
E.coli & $6.7 \mathrm{E}+07$ & $4.1 \mathrm{E}+03$ & 63 & 2.6 & 27 \\
\hline
\end{tabular}

FC: Faecal coliforms; E. coli: Escherichia coli. 
literature reports that the WWTP operated for more than 9 years without cleaning the basins, [4]. We propose a regular cleaning program (every 5 years on average) of the sludge in the anaerobic and facultative basins. Also, we believe that the wastewater from the faecal sludge treatment plant should be sent to the upstream the network, i.e. to the anaerobic ponds instead of the maturation ponds for proper treatment.

\section{Conclusion and Perspectives}

The present study carried out on the wastewater treatment plant of the city of Ouagadougou, allowed us to evaluate the purification performance of the plant after 17 years of operation. It was done on the basis of physicochemical, organic and bacteriological pollution parameters. The physicochemical measurements showed great fluctuation of the $\mathrm{pH}$ values of the raw water, which could cause dysfunctions in the anaerobic basins. The $\mathrm{BOD}_{5}$ removal efficiency of $81 \%$ and the filtered COD of $73 \%$ are satisfactory. The gross COD removal efficiencies of $55 \%$ are acceptable. However, the residual $\mathrm{BOD}_{5}$ concentrations $(219 \mathrm{mg} / \mathrm{L})$ remain higher than the discharge standard for surface water in Burkina Faso (50 $\mathrm{mg} / \mathrm{L}$ ). After 17 years of operation, the plant has very low TSS yields. However, the residual TSS concentrations $(110 \mathrm{mg} / \mathrm{L})$ meet the Burkina Faso standard for discharge of treated wastewater into surface waters $(200 \mathrm{mg} / \mathrm{L})$. Nutrient removal efficiencies (nitrogen and phosphorus) are minimal. However, the residual ammonia nitrogen concentrations in the outflow effluent (on average 12.43 $\mathrm{mg} / \mathrm{L}$ ), do not meet the standard for discharge to surface waters in Burkina Faso $(1.29 \mathrm{mg} / \mathrm{L})$. The bacteriological yields of less than $3 \mu \mathrm{log}$ are less satisfactory. This means that the residual concentrations of bacteria in the treated water remain above the WHO discharge standards if the water was intended for non-restrictive irrigation reuse. In order to solve the problems of dysfunction of the plant and to improve the quality of the effluent at the outlet, we recommend that ONEA take into account all the proposed solutions in order to allow a sustainable and efficient operation of the WWTP.

\section{Acknowledgements}

The authors are grateful to International Science Program (ISP) for supporting their research group BUF 01 and this research works.

\section{Conflicts of Interest}

The authors declare no conflicts of interest regarding the publication of this paper.

\section{References}

[1] Molle, P., Lienard, A., Boutin, C., Merlin, G. and Iwema, A. (2005) How to Treat Raw Sewage with Constructed Wetlands: An Overview of the French Systems. Water Science \& Technology, 51, 11-21. https://doi.org/10.2166/wst.2005.0277 
[2] Konate, Y. (2011) Lagunage anaérobie en climat soudano-sahélien: Performances sludge accumulation, fate of parasites, biogas production (Ouagadougou-Burkina Faso).

[3] Ouattara, R. (2019) Wastewater Treatment and Reuse for Irrigation: The Case of the Kossodo Lagoon-Based Wastewater Treatment Plant. Licence pro in rural hydraulic engineering/Irrigation systems (SI). Ouagadougou, 31/77.

[4] Zongo, et al. (2013) Evaluation of the Purification Performance of the Kossodo Wastewater Treatment Plant after 9 Years of Functioning. Thesis for the Graduate of the Master in Water and Environment Engineering Option: Water and Sanitation.

[5] Prigent, S., et al. (2012) Report of Doctoral Thesis Specialty Process Engineering. University Nantes Angers Le Mans: Optimization of Nitrogen and Phosphorus Treatment of Domestic Wastewater Adapted to Planted Reed Filters, 230 p.

[6] Fagrouch, A., Amyay, S., Berrahou, A., El Halouani, H. and Abdelmoumen, H. (2010) Performance of Pathogen Reduction in Natural Lagooning under Arid Climate: Case of the Wastewater Treatment System of the City of Taourirt. Afrique Science, 6, 87102.

[7] Sou, Y.M. (2009) Wastewater Recycling in Irrigation: Fertilizer Potential, Health Risks and Impacts on Soil Quality. 200 p.

[8] Yulistyorini, A., Kumala Puspasari, A., Mujiyono, and Anindya Sari, A. (2019) Removal of BOD and TSS of Student Dormitory Greywater Using Vertical Sub-Surface Flow Constructed Wetland of Ipomoea Aquatica. IOP Conference Series. Materials Science and Engineering, 515, 012056. https://doi.org/10.1088/1757-899X/515/1/012056

[9] Sawadogo, J., et al. (2016) Planted Sludge Drying Beds in Treatment of Faecal Sludge from Ouagadougou: Case of Two Local Plant Species. Journal of Water Resource and Protection, 8, 697-705. https://doi.org/10.4236/jwarp.2016.87057

[10] Mimeche, L., Mancerh and Debabeche, M. (2010) Tunisian Journal of Medicinal Plants and Naturel Products, 4.

[11] Lombard-Latune, L., Mangeot, L., Pelus, L., L'etang, F., Fina, N., Le Guennec, B. and Molle, P. (2016) Compact Unsaturated/Saturated Vertical Flow Constructed Wetland System under Tropical Conditions: Nitrogen Removal and Foot Print Reduction. In: Magdalena, G., Karolina, M.-Ł. and Ewa, W., Eds., 15th International Conference on Wetland Systems for Water Pollution Control. Vol. 1, International Water Association, Gdansk, 367. 